\title{
Essential oils on the control of stem and ear rot in maize
}

\author{
Óleos essenciais no controle da podridão do colmo e da espiga em milho
}

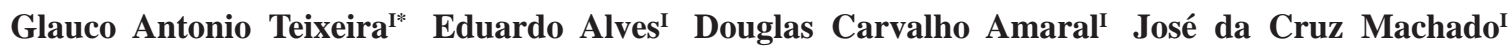 \\ Fabiano José Perina ${ }^{\mathrm{I}}$
}

\section{ABSTRACT}

Stem and ear rot caused by Stenocarpella maydis are responsible for severe losses in maize production. Treatment of seeds with fungicides may induce environmental damage. Hence, this study aimed to evaluate the effects of essential oils extracted from Cymbopogon winterianus, Thymus vulgaris, Cymbopogon citratus, Corymbia citriodora, Cinnamomum zeylanicum, and Syzygium aromaticum on the development of in vitro $S$. maydis. In addition, maize seeds were treated with these essential oils to determine their possible mode of action and effects. The oils from S. aromaticum, C. zeylanicum, and T. vulgaris inhibited fungal development at concentrations higher than $0.025 \%$. The oils from S. aromaticum and $\boldsymbol{C}$. zeylanicum showed seed germination rates of $89.0 \%$ and $84.5 \%$, which were higher than that of the control. The oils from S. aromaticum and $\mathbf{C}$. zeylanicum reduced the pathogen incidence in the seeds to $39.0 \%$ and $28.0 \%$, respectively. Further, these oils as well as that from T. vulgaris produced lower reduction of maize stand. Scanning electron microscopy examination revealed that essential oils from $\boldsymbol{S}$. aromaticum and $\boldsymbol{T}$. vulgaris acted directly on the conidia, impeding germination. The findings suggest that the oils from S. aromaticum, C. zeylanicum, and T. vulgaris are potential alternatives for maize seed treatment in the control of $\mathbf{S}$. maydis.

Key words: Stenocarpella maydis, Zea mays, alternative control, electron microscopy.

\section{RESUMO}

A podridão-do-colmo e espiga, causada por Stenocarpella maydis, é responsável por graves perdas na produção de milho. $O$ tratamento de sementes com fungicidas pode provocar danos ambientais. Por isso, este estudo objetivou avaliar o efeito de óleos essenciais extraídos de Cymbopogon winterianus (citronela), Thymus vulgaris (tomilho), Cymbopogon citratus (capim-limão), Corymbia citriodora (eucalipto), Cinnamomum zeylanicum (canela) e Syzygium aromaticum (cravo-da-Índia) sobre o desenvolvimento de S. maydis in vitro.
Além disso, sementes de milho foram tratadas com esses óleos essenciais para determinar seus possíveis modos de ação e efeitos. Os óleos de S. aromaticum, C. zeylanicum e T. vulgaris inibiram o desenvolvimento do fungo nas concentrações maiores que 0,025\%. Os óleos de $\boldsymbol{S}$. aromaticum e $\boldsymbol{C}$. zeylanicum mostraram taxas de germinação de sementes de $89,0 \%$ e $84,5 \%$, as quais foram maiores que a testemunha. Esses óleos reduziram a incidência do patógeno nas sementes para 39,0\% e 28\%, respectivamente. Além disso, esses óleos, bem como o óleo de T. vulgaris, produziram menor redução do estande de milho. O exame de microscopia eletrônica de varredura revelou que os óleos de S. aromaticum and T. vulgaris agiram diretamente sobre os conídios, impedindo a germinação. Os resultados deste trabalho sugerem que os óleos de S. aromaticum, $\boldsymbol{C}$. zeylanicum e $\boldsymbol{T}$. vulgaris são alternativas potenciais para o tratamento de sementes de milho no controle de S. maydis.

Palavras-chave: Stenocarpella maydis, Zea mays, controle alternativo, microscopia eletrônica.

\section{INTRODUCTION}

Stenocarpella maydis (Berk.) Sutton [syn. Diplodia maydis (Berk.) Sacc.] is the causal agent of one of the main diseases in maize, the stem and ear rots. It is widely distributed in the areas of maize production in Brazil. Besides its effect on productivity, it is one of the major pathogens that affects the quality of seeds and grains of maize. The main symptoms of $\boldsymbol{S}$. maydis infection are grain rot, stem and ear rot, and leaf spots (BRESSAN \& FIGUEIREDO, 2005). This pathogen shows variable occurrence depending on rainfall regime and temperature and is effectively transmitted via

IDepartamento de Fitopatologia, Universidade Federal de Lavras (UFLA), 37200-000, Lavras, MG, Brasil. E-mail: glauco@posgrad.ufla. br. *Autor para correspondência. 
seeds. Considerable losses are observed in the field under high humidity conditions, especially when the harvest period is increased (CASA et al., 2006).

Treatment of seeds is the most important measure to control the disease and protect the physiological quality of seeds. Chemical treatment ensures application throughout the surface of the seeds, as well as is economical, considering the low concentrations of active ingredients used (MACHADO et al., 2004). However, extensive use of chemicals in the control of the diseases and pests in agriculture increases environmental and toxicological risks and thus identifying alternative methods becomes necessary. Essential oils extracted from some plants species has shown to have promising economic and ecological advantages. KISHORE et al. (2007) verified that the clove oil and cinnamon oil reduced the pre emergence rotting and the post emergence wilting in peanut seeds Aspergilus nigerinfested soil. Also, MEDICE et al. (2007) observed the oils such as $\mathbf{T}$. vulgaris reduced the severity of soybean rust disease in $30 \%$. The parasitic relationship between $\boldsymbol{S}$. maydis and maize leaves may be well understood using the Scanning electron microscope (SEM) analysis, which is a valuable tool to study adhesion, germination, penetration, colonization, and reproduction of pathogens (ALVES et al., 2008). In this way, BRUNELLI et al. (2005) and MEDICE el at. (2007) verified that the essential oils act on the conidia germination and on the appessorium formation as well. Therefore, this study aimed to evaluate the effects of essential oils extracted from Cymbopogon winterianus (citronella), Thymus vulgaris (thyme), Cymbopogon citratus (lemon grass), Corymbia citriodora (eucalyptus), Cinnamomum zeylanicum (cinnamon), and Syzygium aromaticum (India clove) on the development of in vitro S. maydis and on corn seeds inoculated with $\boldsymbol{S}$. maydis. The ultrastructural aspects of the association of this pathogen with maize leaf tissues were also assessed.

\section{MATERIAL AND METHODS}

The experiments were conducted at the Laboratories of Seeds Health and Electron Microscopy and Ultrastructural Analysis (LME), Plant Pathology Department, Federal University of Lavras (UFLA). The essential oils were provided by Brasil Portrait Cosméticos Ltda, Sorocaba, SP, Brazil, register codes (7898202871725, 7898202871749, 7898202871756, 7898202871763, 7898202871787).

The $S$. maydis isolate was recovered from maize seeds by using the seed health test, incubation on paper substrate (blotter-test). A single spore was collected and grown in potato dextrose agar (PDA) medium, and then preserved at the UFLA Mycology Collection.

First, the inhibition of conidial germination was assessed using enzyme-linked immunosorbent assay (ELISA) plates and by examining individual conidia under a light microscope. The essential oils from citronella, thyme, lemon grass, eucalyptus, cinnamon, and India clove were used at concentrations of $0.05,0.2,0.35$, and $0.5 \%$; the control treatment included sterilized distilled water and a fungicide (fludioxonil + metalaxyl; Maxim $\mathrm{XL}^{\circledR}$ ) was used at the concentration of $0.1 \%$. The experiments were conducted in 8 replicates in a completely randomized design (CRD). In each ELISA plate well, $40 \mu \mathrm{L}$ each of the oil solution and conidial suspension adjusted to $10^{4}$ conidia $\cdot \mathrm{mL}^{-1}$ were added. The plate was incubated at $25^{\circ} \mathrm{C}$ for $15 \mathrm{~h}$ under a photoperiod of $12 \mathrm{~h}$, and then $20 \mu \mathrm{L}$ of lactophenol was added to each well of the plate. In all, 50 conidia were examined per experimental plot, totaling 400 conidia per treatment.

For the evaluation of mycelial growth, $9 \mathrm{~mL}$ of autoclaved PDA medium was added to petri dishes, followed by addition of a $1 \mathrm{~mL}$ pre-mixture of oil and water $(10 \mathrm{x})$ containing $1 \%$ Tween 20 . In the center of each dish, a 6-mm diameter disk containing 7-day-old mycelium developed on PDA was deposited, corresponding to the experimental plot. This assay was also conducted in a CRD; the concentrations of essential oils used in this assay were $0.1,0.5,1.0$, and $2.0 \%$, along with the control and fungicide Maxim $\mathrm{XL}^{\circledR}$ at $0.1 \%$; the experiment was conducted in 4 replicates. The dishes were placed in an incubator at $25^{\circ} \mathrm{C}$ under a 12 -h photoperiod. The negative control consisted of a disk of the fungal mycelium on the medium composed of $9 \mathrm{~mL}$ of PDA plus $1 \mathrm{~mL}$ sterile distilled water plus $1 \%$ Tween 20 , and the positive control included the fungicide. The colony diameters in the petri dishes were measured daily, during 7 days. The results were converted to mycelial growth index (MGI) to be adapted to the formula described by MAGUIRE (1962).

The seeds of the hybrid BX945, susceptible to $S$. maydis, were inoculated through the osmotic conditioning technique described by MACHADO et al. (2004), with some modifications. For this assay, $0.1 \%$ of essential oils of India clove, cinnamon, and thyme were used, as described previously. The treatments consisted of these 3 essential oils, the fungicide at $0.1 \%$, non-inoculated seeds, a control containing only restrictor hydric (mannitol), and another control representing the original seed lot, totaling 7 treatments with 4 replicates. 
After inoculation, seeds were subdivided into 7 samples, each with 200 seeds. The samples were immersed separately for $5 \mathrm{~min}$ in solutions corresponding to the respective treatments and dried on sterilized filter paper at room temperature. Dried seeds were submitted to the health blotter method for 14 days as described by BRASIL (2009), and then examined under a stereomicroscope for the determination of $\boldsymbol{S}$. maydis incidence. Seed germination was evaluated using the standard method described in the Rules for Seed Analysis in Brazil (BRASIL, 2009).

For the evaluation of seed vigor, treated and non-treated seeds were submitted to standard emergence method and cold test. For the standard emergence test, the seeds were first disinfested with $1.0 \%$ sodium hypochlorite solution for $2 \mathrm{~min}$ and then treated as previously described. The seeds were sowed in plastic trays containing $5 \mathrm{~L}$ of the substrate Plantmax $^{\circledR}$ and sand (2:1), and both were autoclaved earlier. The numbers of emerged seedlings were counted daily, until emergence stabilization. The emergence seed index (ESI) was calculated using the formula suggested by MAGUIRE (1962). Next, the initial and final plant populations (stands) were counted at 10 and 28 days after sowing.

For the cold test, trays containing $5 \mathrm{~L}$ of substrate consisting of soil and sand mixture (2:1) were used. The soil was collected from an area previously cultivated with maize. The water supply was as adjusted to the reference level of $70 \%$ of the substrate retention capacity. The trays were placed in a cold chamber at $10^{\circ} \mathrm{C}$ in the dark for 7 days. Subsequently, the trays were transferred to a growth chamber at $25^{\circ} \mathrm{C}$ with a 12 -h photoperiod. The numbers of emerged seedlings were counted after 5 days.

Another experiment was conducted using health maize leaves obtained from plants cultivated in a greenhouse. Two 20 -cm pieces of leaves were placed in a plastic tray containing filter paper moistened with sterilized distilled water and covered with aluminum foil. Next, $40 \mu \mathrm{L}$ of the pre-mixed suspension adjusted to $7.5 \times 10^{4}$ spores $\cdot \mathrm{mL}^{-1}$ was added to the solution of each treatment. The treatments consisted of oil solutions from clove, cinnamon, and thyme; the fungicide Maxim $\mathrm{XL}^{\circledR}$ at the concentration of $0.1 \%$; and positive and negative controls. The suspension was applied in pre-defined places on the lower surface of the leaves such that samples could be collected with fragments of approximately $0.5 \mathrm{~cm}$. These fragments were collected at $3,7,11,15,20,25,30,35,40$, and $45 \mathrm{~h}$ after inoculation. The collected fragments were fixed in modified Karnovsky's solution, and then treated as described by ALVES et al. (2008). The number of germinated conidia were also counted by selecting a specific area on the leaf surface; the data were transformed to percentage rate.

The data were analyzed using analysis of variance by using the software R Core Development Team (VENABLES \& SMITH, 2010), and the treatment results were compared using Scott-Knott test $(\mathrm{P}<0.05)$.

\section{RESULTS}

Conidia germination was reduced by all treatments except for $0.05 \%$ citronella oil, which enhanced conidial germination. Furthermore, eucalyptus oil and fungicide treatment produced an intermediate effect on conidial germination compared to the control (Figure 1).

Mycelial growth of $\boldsymbol{S}$. maydis and maize seed emergence did not vary significantly between $1.0 \%$ citronella, $0.1 \%$ lemongrass, and $0.1 \%$ and $0.5 \%$ eucalyptus oil extracts and control. On the other hand, thyme and India clove oil extracts and the fungicide completely inhibited mycelial growth of the fungus. Similarly, $0.5 \%$ and higher concentrations of cinnamon and lemongrass oil extracts and 2.0\% and higher concentrations of eucalyptus oil showed higher mycelial growth inhibition. In contrast, citronella oil stimulated the mycelial growth of the fungus (Table 1).

S. maydis was not found in non-inoculated seeds in these experiments. However, the fungus was found in small numbers in the cinnamon, followed by India clove oil-treated groups, although the latter did not differ significantly from the fungicide-treatment group. The positive control and thyme oil-treated groups showed significantly higher numbers of the fungi compared to all other treatment groups. The emergence and cold tests did not yield significantly different results among the treatment groups, except for seeds treated with mannitol, which showed significantly lower emergence rate than that in the other treatment groups in the cold test (Table 1). $\boldsymbol{S}$. maydis produced $21 \%$ reduction in seed germination. On the other hand, treatment with all essential oils led to a lower rate of stand reduction (final stand - initial stand), followed by that in the fungicide-treated group and the positive control. However, the control group with mannitol and the negative control group produced a lower reduction of stand index (Table 1).

In non-treated maize leaves, conidia germination was not observed up to $3 \mathrm{~h}$ after 


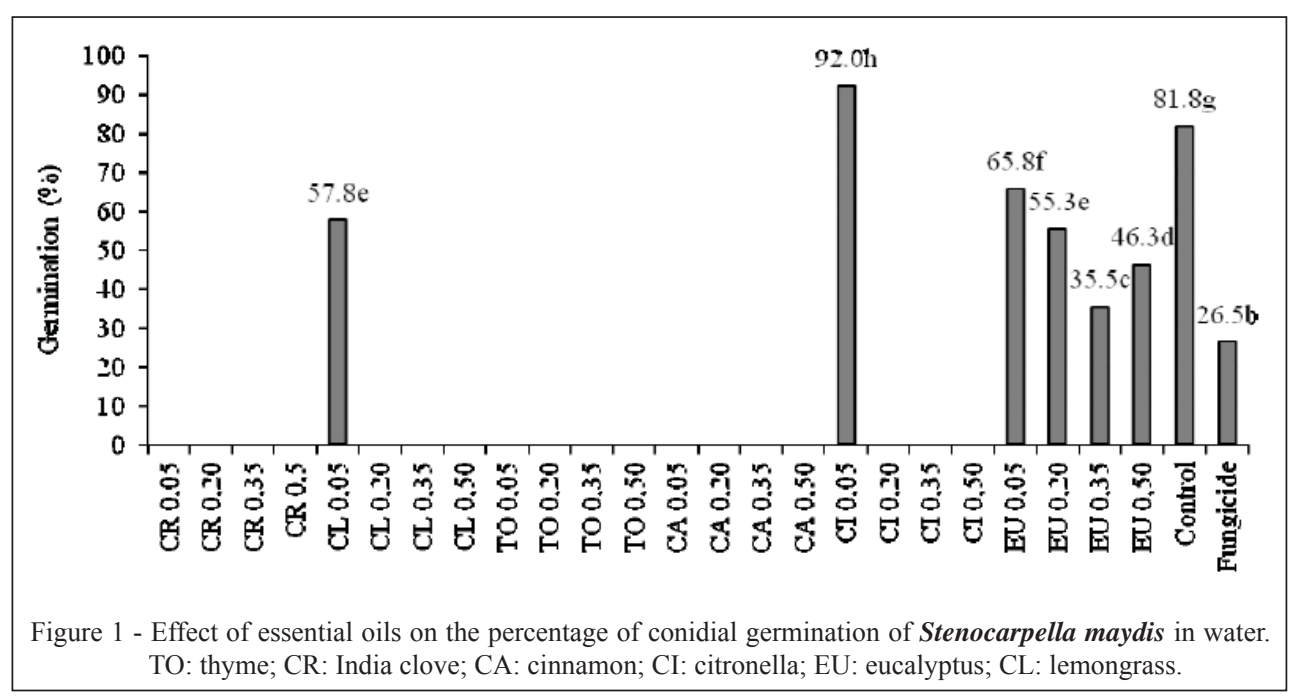

inoculation (h.a.i.; Figure 2A). Conidial germination started from 7h.a.i. (Figure 2B) and was more pronounced between 11 and 15h.a.i, when 87.5\% germinated conidia were observed (Figure $2 \mathrm{C}$ ). The onset of appressorium formation occurred between 11 and 20h.a.i. and conidial penetration began at 20h.a.i. (Figure 2D and 2F). At 25 h.a.i, 92\% of the conidia had been germinated and 50\% had appressoria. From 35 h.a.i., elongation of the germ tube and development of the penetration structures of the fungus were observed (Figure 2E).

In leaves treated with cinnamon, India clove, and thyme oil extracts, conidial germination began between 11 and 15 h.a.i. In the leaves treated with cinnamon and thyme, appressorium formation occurred between 15 and 25 h.a.i., and elongation of the germ tube started from 20h.a.i (Figure 2G). However, for leaves treated with India clove oil, appressorium formation was observed at 25h.a.i., with no elongation of the germ tube (Figure $2 \mathrm{H}$ ). The leaves treated with India clove and thyme oils showed wilting of some of the germ tubes and penetration structures at 30h.a.i (Figure 2I). In the leaves treated with the fungicide, germination was observed only in a few conidia starting at 30 h.a.i., and appressorium formation and elongation of the germ tube were not observed up to 45 h.a.i. (Figure 2J).

\section{DISCUSSION}

The control of several pathogenic fungi in maize has been successful achieved by treating seeds with chemical fungicides. Depending on factors such as seed physiological quality and inoculum potential of the pathogens in the seed lot, the efficacy of such treatment may vary. With the increase of maize cultivated area in Brazil, the volume seed lots subjected to fungicide treatment also increases, causing a concern from the pollution point of view. In this study, the potential of essential oils extracted from some plant species such as India clove, thyme, and cinnamon used as alternatives for the control of pathogenic fungi was assessed. In the bioassay, all oils completely inhibited mycelial growth and germination of $\boldsymbol{S}$. maydis at concentrations higher than $0.5 \%$. Similar results has been obtained by other studies that used garlic extracts (Allium sativum) and lemongrass (Cymbopogon citratus) at an initial concentration of $0.5 \%$ to study the effect on mycelial growth and germination of Fusarium proliferatum conidia (SOUZA et al., 2007). Similarly, essential oils from sage, garlic, and cinnamon were found to inhibit mycelial growth of Aspergillus flavus isolates (VIEGAS et al., 2005). LIMA et al. (2006) indicated that the oils from cinnamon (Cinnamomun zeylanicum) and Chilean boldo (Peumus boldus) inhibited the growth of $58 \%$ of Candida species strains.

Regarding the effect on the quality of maize seeds, S. maydis was responsible for $21 \%$ reduction in seed germination, and none of the treatments was able to eliminate the fungus from infected seeds. Nonetheless, treatment of seeds with the essential oil from cinnamon at $0.1 \%$ dose reduced S. maydis incidence by $49 \%$. Similar reduction in fungal incidence has been reported for other cases such as Fusarium proliferatum following treatment of maize seeds with garlic extract (Allium sativum) 
Table 1 - Mycelial growth index (MGI) of Stenocarpella maydis; seed germination and vigor and incidence of $\boldsymbol{S}$. maydis in maize seeds treated with essential oils; plant stand size at 10 and 28 days after sowing .

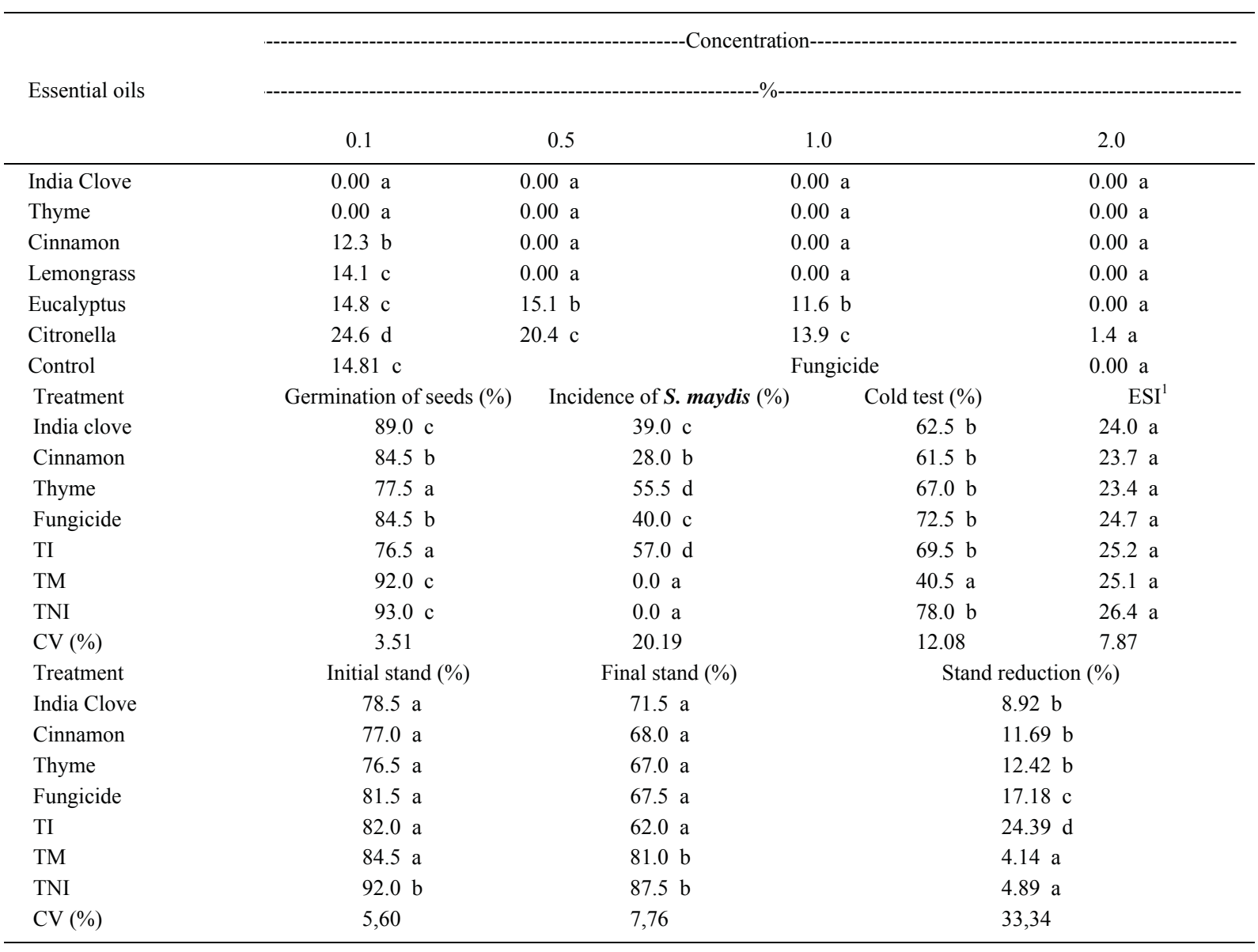

Means followed by the same letter do not differ significantly from the values presented in that column by Scott-Knott test $(\mathrm{P}<0.05)$.

${ }^{1}$ Emergence seed index.

(TI) inoculated control, (TM) control only with mannitol, and (TNI) non-inoculated control.

and lemongrass (Cymbopogon citratus) (SOUZA et al., 2007). This led to an increase of $24 \%$ in the germination percentage of the seeds.

By SEM, appressorium formation was observed after $72 \mathrm{~h}$ of incubation at $25^{\circ} \mathrm{C}$. However, BENSCH \& STADEN (1992) showed that the germination of $\boldsymbol{S}$. maydis conidia in the stems and corn leaves occurred after $5 \mathrm{~h}$ of incubation at $30^{\circ} \mathrm{C}$. In addition, seeds treated with the essential oils from India clove, cinnamon, and thyme delayed the germination of $\boldsymbol{S}$. maydis conidia by about $5 \mathrm{~h}$. However, for leaves treated with India clove oil, appressorium formation occurred at $25 \mathrm{~h}$ after inoculation. In the same way, BRUNELLI et al. (2005) conducted SEM analysis and found that $86 \%$ of the conidia of Stenocarpella macrospora germinated between 12 and $15 \mathrm{~h}$ after inoculation and appressorium formation occurred at 18h.a.i. Furthermore, oils from India clove and thyme caused wilting of some conidia at 30h.a.i.; this finding is similar to that reported by MEDICE et al. (2007) who evaluated the effect of essential oils applied on soybean leaves surface on spore germination of Phakopsora pachyrhizi.

The results suggest that treatment of maize seeds with essential oils from India clove, cinnamon, and thyme, at the concentration of $0.1 \%$, mighty play an important role in the control of stem and ear rot fungus. Besides having a direct effect on the development of $\boldsymbol{S}$. maydis in vitro colonies these oils suppressed the proliferation of the fungus in maize plant tissues. The use of these oils may contribute to higher maize seed quality ensuring a desired plant population in the field, without causing any risk to man or the environment. 

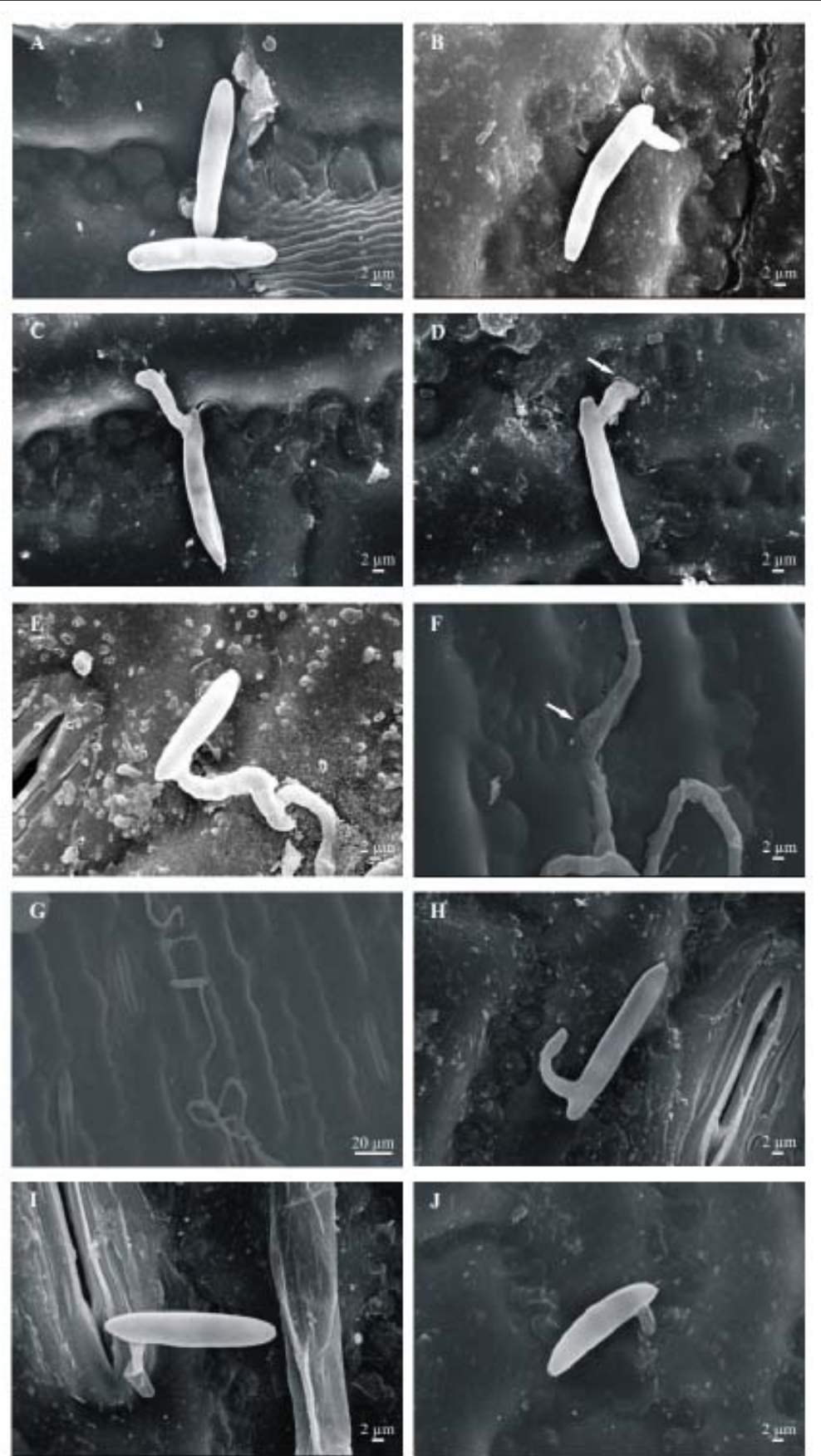

Figure 2 - Scanning electron micrographs of corn leaves inoculated with Stenocarpella maydis $(\mathrm{A}-\mathrm{F})$ and treated with essential oils $(\mathrm{G}-\mathrm{J})$. Conidia are not germinated (3 h.a.i.) (A), Conidium at the beginning of germination ( 7 h.a.i.) (B), Initial formation of appressorium (11h.a.i.) (C), Appressorium formed (20h.a.i.) (D), Germ tube elongation (30h.a.i.) (E), Penetration of the fungus by appressoria (20h.a.i.) (F), Elongation of the germ tube and penetration by appressorium in leaves treated with essential oil from cinnamon (20h.a.i.) (G), Appressorium formation in leaves treated with essential oil from India clove (25h.a.i.) (H), Wilted germ tube in leaves treated with essential oils from thyme and India clove (30h.a.i.) (I), Beginning of conidial germination in a leaf treated with fungicide (40h.a.i.) (J). 


\section{REFERENCES}

ALVES, E. et al. Ultra-estrutura na era do DNA. In: PASCHOLATI, S.F. et al. Interação planta-patógeno: fisiologia, bioquímica e biologia molecular. Piracicaba: Fealq, 2008. V.1, p.433-466.

BENSCH, M.J.; STADEN, J. VAN. Ultrastructural histopathology of infection and colonization of maize by Stenocarpella maydis (= Diplodia maydis). Journal of Phytopathology, Berlín, v.136, n.4, p.312-318, 1992.

BRASIL. Ministério da Agricultura e Reforma Agrária. Tolerâncias. In: Regras para análise de sementes Brasília, DF: MAPA/ACS, 2009. 395p.

BRESSAN, W.; FIGUEIREDO, J.E.F. Biological control of Stenocarpella maydis in maize seed with antagonistic Streptomyces sp. Isolates. Journal of Phytopathology, Berlín, v.153, n.10, p.623-626, 2005.

BRUNELLI, K.R. et al. Germinação e penetração de Stenocarpella macrospora em folhas de milho. Fitopatologia Brasileira, Viçosa, v.30, n.2, p.187-190, 2005.

CASA, R.T. et al. Doenças do milho causadas por fungos do gênero Stenocarpella. Fitopatologia Brasileira, Viçosa, v.31, n.5, p.427-439, 2006

KISHORE, G.K. et al. Evaluation of essential oils and their components for broad-spectrum antifungal activity and control of late leaf spot and crown rot diseases in peanut. Plant Disease, Saint Paul, v.91, n.4, p.375-379, 2007

LIMA, I.O. et al. Atividade antifúngica de óleos essenciais sobre espécies de Candida. Brazilian Journal of Pharmacognosy, Curitiba, v.16, n.2, p.197-201, 2006.

MACHADO, J.C. et al. Use of water restriction technique in seed pathology. Seed Testing International, ISTA News Bulletin, v.128, p.14-18, 2004.

MAGUIRE, J.D. Speed of germination-aid in selection and evaluation for seedling emergence and vigor. Crop Science, Madison, v.2, n.1, p.176-177, 1962.

MEDICE, R. et al. Óleos essenciais no controle da ferrugem asiática da soja Phakopsora pachyrhizi Syd. \& P. Syd. Ciência e Agrotecnologia, Lavras, v.31, n.1, p.83-90, 2007.

SOUZA, A.E.F. et al. Atividade antifúngica de extratos de alho e capim-santo sobre o desenvolvimento de Fusarium proliferatum isolado de grãos de milho. Fitopatologia Brasileira, Viçosa, v.32, n.6, p.465-471, 2007.

VENABLES, W.N.; SMITH, D.M. R Development core team. An introduction to R notes on R. A Programming Environment for Data Analysis and Graphics $\mathbf{R}$ core team version, v.2, n.1, 103p., 2010.

VIEGAS, E.C. et al. Toxicidade de óleos essenciais de alho e casca de canela contra fungos do grupo Aspergillus flavus. Horticultura Brasileira, Brasília, v.23, n.4, p.915-919, 2005. 